\title{
Benefits of DfX in Requirements Engineering
}

\author{
Jari Lehto ${ }^{1}$, Janne Harkonen ${ }^{2}$, Harri Haapasalo ${ }^{2}$, Pekka Belt ${ }^{2}$, Matti Mottonen ${ }^{2}$, Pasi Kuvaja ${ }^{2}$ \\ ${ }^{1}$ Nokia Siemens Networks, Espoo, Finland \\ ${ }^{2}$ University of Oulu, Oulu, Finland \\ E-mail: jari.lehto@nsn.com, \{janne.harkonen, harri.haapasalo, pekka.belt, matti.mottonen, pasi.kuvaja\}@oulu.fi \\ Received November 9, 2010; revised December 6, 2010; accepted January 5, 2011
}

\begin{abstract}
Information and communications technology (ICT) companies have realised how acknowledging the needs of both internal and external customers is a necessity for successful requirements engineering. Design for $\mathrm{X}$ (DfX) is a potential management approach for coordinating \& communicating requirements emerging from both internal functions and external supply chain partners. This article studies the potential of DfX for improved requirements engineering. Qualitative interviews are utilised to analyse how different organisations implement the concept, including designers' actual work, methods \& tools, and organisational aspects. The results include viewing DfX as means to achieve relevant competitive goals, and describing how different companies organise these activities, together with their benefits for modern ICT companies. This study highlights how the DfX concept can be used to manage, prioritise and to better communicate requirements.
\end{abstract}

Keywords: Design for X, ICT, Design for Excellence, Requirements Engineering, Requirements, Industrial Management, Product Development, Delivery Capability, Management, Communication, Technology, Competitive Goals

\section{Introduction}

The information and communications technology (ICT) sector is going through an ongoing transformation in its product development (PD), while facing increasing product complexity, and fragmentation of customer segments. Companies work in a multi-project, multi-site, multicultural, multi-vendor environment where organisational changes are common. During the past decade, there has been an inclination to relocate production, while new government supported Asian competition has emerged. This type of changes, combined with severe price erosion and demands for shortening product development times, require special attention on assuring quality and relevant competitive goals, such as delivery capability, cost, flexibility and others. Striving for business success in this type of environment is seen to require the integration of engineers, industrial designers, methods \& tools, and organisational aspects. [1-4].

Due to fierce global competition, companies can either consider transferring production lines from one country to another, or rationalise locally, in order to cut costs [5]. Nevertheless, cost being a vital consideration, it is only one of the competitive aspects that can be influenced during product development.
Many authors have stressed the significance of early steps of PD [6-11]. The possibilities of influencing PD success are seen to be at best during the early project stages. The decisions made early, reduce unnecessary changes during later PD stages, and even the total lifecycle costs. Design for X (DfX) is a structured means to systematically address the early product development, functional integration, and enable capability creation [12-14].

Catering for the needs of internal customers has been recognised vital for successful PD [15-16]. Effective product development is a necessity for achieving competitive goals, and to tackle price erosion. Different aspects internal to companies have been addressed by utilising the DfX methodology, including different disciplines, such as assembly and manufacturing in general. The methodology has later expanded to cover also other relevant aspects, including environment and many others [17].

Design requirements for products tend to develop during $\mathrm{PD}$, and managing requirements has become an ever greater challenge for ICT companies. Requirements are also interpreted differently in different parts of organisations, amplifying the communication challenge. In addition, already Bruce et al. [18] highlight requirements capture activities for an environment with considerable 
competitive pressures. Design for $\mathrm{X}$ is a prospective management approach for coordinating and communicating the design requirements of both, internal functions and external supply chain partners. Aside realising the implementation of different practices in various DfX disciplines, DfX can also be used for gathering best practices and disseminating requirements information. DfX methodologies have been widely discussed in the literature for over a decade, however practical descriptions on how companies organise these activities are limited. [19-21].

This paper studies the Design for $\mathrm{X}$ practices in ICT companies. The study includes a successful ICT company utilising DfX as a management approach and several smaller actors. The analysis aims to clarify the required organisation and practical realisation of these activities.

The above mentioned can be condensed into the following research questions:

RQ1. What benefits does the DfX concept provide for modern ICT companies?

RQ2. How are the DfX concept, principles, and tools organised in selected companies?

The first research question is addressed, both theoretically and by analysing different ICT companies. The second research question is addressed through a qualitative interview study.

\section{Literature Review}

Product - production process interface has traditionally been addressed under the concepts of design for manufacturing (DfM) and design for assembly (DfA) [22-25]. However, some recent research, also focus on the interface between product and demand chain, including the aspects of delivery and service capability [13,26]. In general, it is mainly three core business processes that generate value for customers. These include product development management, supply chain management, and customer relationship management [27].

In order to make products, a company needs a product development process, including preparation for production. This is regardless that there is no uniform conception of what constitutes a product development process, and that it may differ by industry and possibly by a company [28]. It has been known already for some time that it may be possible to improve product development efficiency and effectiveness by simultaneously designing products and related production processes, rather than designing them separately or in a sequential manner [29-30]. Automotive industry, especially Toyota, provides a good example of simultaneous product and process design, as each new model typically requires a new assembly line [31-33].

The practice of simultaneously considering a number of development aspects is known as concurrent engineering [34]. Concurrent engineering, typically seen to include product and process considerations [35], but some authors also include supply chain as the third dimension [26,36]. Successes in improvements, considering cost, delivery, flexibility, and quality have been reported in companies through implementing different initiatives, including concurrent engineering. These improvements are also referred to as capability improvements [37]. As a consequence concurrent engineering is seen as a mechanism that can improve an organisation's competitive capabilities and reduce ambiguousness [38].

Concurrent engineering (CE) can include the consideration of a number of factors, such as manufacturing, quality, logistics, assembly, packaging, reliability, service, and so on. This challenge of designing for different factors, X's, often also referred to as DfX [9,17]. Design for something, $X$ 's, conveys the intended aim better than $\mathrm{CE}$, as the latter does not specify what is to be done or why. DfX methodologies have traditionally been driven by cost competition and product life-cycle considerations. This is highlighted by the estimates, as high as $70 \%$, of total life-cycle costs of products being committed at early design stages [39-40]. Even though DfX methodologies have, at least to some degree, proven successful in reducing costs, the design evaluation criterion in most of these is not costs. This is why other means are seen to be required to provide cost information to designers. $[39,41]$. Also, labour is not the major cost component, but overhead costs and material costs that are seen to have become the main elements of product cost [40-42].

Companies can be seen to have five primary competitive goals, or competencies, including cost, quality, delivery, flexibility, and innovation [43]. Different competitive goals may be highlighted through products life. Also, the focus of product - process interface may need to be different at different stages of a product's life, including introduction, growth, maturity and decline [44]. Magnan et al. [45] have studied the importance of different competitive goals through a product's life, indicating that innovation, both process and product, are important during the early stages, and delivery capability and flexibility are highlighted during growth and maturity. Quality is seen to be highlighted during product introduction and growth and cost during maturity. Companies need to have the means to effectively stress competitive goals relevant at different stages of a product's life. DfX methodologies are seen as a potential means for improving communication and creating capabilities for addressing the competitive goals [13]. Table 1 lists different business benefits obtainable through diverse DfX considerations. Some of these benefits are indirect, experienced through DfX realisation. 
Table 1. Business benefits supported by DfX realisation.

\begin{tabular}{|c|c|c|}
\hline DfX consideration & Obtained benefits & \\
\hline Cost & $\begin{array}{l}\text { Profit in price competitive mar- } \\
\text { kets }\end{array}$ & {$[46-51]$} \\
\hline Quality & $\begin{array}{l}\text { Consistent, low defect rates } \\
\text { Optimal product performance } \\
\text { Reliable products }\end{array}$ & $\begin{array}{l}{[6,17,22,24,46,} \\
52-53]\end{array}$ \\
\hline Services & $\begin{array}{l}\text { Effective after-sales service } \\
\text { Effective product support } \\
\text { Effective maintenance } \\
\text { Customisation of products \& } \\
\text { services } \\
\text { Availability of products }\end{array}$ & {$[17,54-60]$} \\
\hline Delivery & $\begin{array}{l}\text { Fast deliveries } \\
\text { On-time deliveries } \\
\text { Time-to-market }\end{array}$ & {$[13,61-64]$} \\
\hline Flexibility & $\begin{array}{l}\text { Design changes } \\
\text { Rapid volume changes } \\
\text { Rapid new product introduc- } \\
\text { tions }\end{array}$ & {$[65-67]$} \\
\hline Manufacturing & $\begin{array}{l}\text { Selection of appropriate proc- } \\
\text { esses } \\
\text { Selection of appropriate materi- } \\
\text { als } \\
\text { Appropriate modular design } \\
\text { Use of standard components }\end{array}$ & {$[17,22-23,66,68]$} \\
\hline Supply chain & $\begin{array}{l}\text { Optimal lead-time } \\
\text { Optimal product diversity }\end{array}$ & {$[62,69-71]$} \\
\hline Assembly & $\begin{array}{l}\text { Economical assembly } \\
\text { Effective part handling and } \\
\text { insertion }\end{array}$ & {$[17,22-23]$} \\
\hline Testability & $\begin{array}{l}\text { Optimal test coverage } \\
\text { Reveal faults and improve reli- } \\
\text { ability } \\
\text { Controllability } \\
\text { Observability }\end{array}$ & {$[72-77]$} \\
\hline Environment & $\begin{array}{l}\text { Sustainable development } \\
\text { Minimise the overall environ- } \\
\text { mental impact }\end{array}$ & {$[17,24,78-81]$} \\
\hline
\end{tabular}

Organising DfX can roughly be divided into the following three domains: 1) designer, 2) methods \& tools, and 3 ) organisation. Designer is typically a skilled R\&D engineer, applying DfX principles in practice. Methods can be seen as procedures and guidelines that the designer follows. Typical tools utilised for communicating requirements include spreadsheets, software, data-bases, matrices for design structure, morphological charts, and such. Organisational aspects cover issues, such as teamwork, collaboration, communication, processes, and company policies [82-86]. In addition, a prototype or clear design guidelines are required for successful DfX realisation [6].

Individual designers, applying DfX, have traditionally focused on product and the value it can provide to the end-user [6]. However, typically, they do not consider different aspects through a product's life, including manufacturing, service, and disposal. These issues are often addressed only after the design is complete, and are left for related departments to solve. This has resulted in cumbersome processes that are inflexible, time-consuming, and prone to errors [25]. Also, timing and balancing of DfX activities are seen vital, but not widely discussed in the literature [13]. The literature presents some critics for DfX, as applying these practices, especially in large organisations poses difficulties due to complex organisational structures, and overwhelming number of issues to be considered [87]. However, practical descriptions on how companies organise DfX activities in practice are limited [19-21].

\section{Research Process}

The research process is described in Figure 1. Design for $\mathrm{X}$ was first studied by using existing literature as the key source. Studied case companies were then examined in order to clarify how a large benchmark company with an existing DfX organisation and seven control group companies address similar challenges. Several workshops were organised to discuss the practical realisation of DfX in the benchmark company that was identified to be successfully applying the methodology. Interview questions were formulated based on the understanding obtained through the literature and the arranged workshops, see Appendix A. The interview questions were validated in the arranged workshops prior to conducting the interviews.

The study consisted of twenty interviews in the bechmark company, comprising multiple sites and countries. The study included all the managers involved with DfX as well as responsible managers for vital internal processes.

Interviews in the control group companies include seven companies, most of which are SMEs. One key person was interviewed in each, utilising a slightly different questionnaire, see Appendix B. The questionnaire was modified with an assumption that all the companies were not necessarily aware of the term DfX. All the interviews were transcribed and analysed.

The research utilised a semi-structured thematic interview approach [88]. The interviews were conducted informally, in a qualitative manner, allowing the interviewees to explain and clarify the cases and topics as entities. Therefore, these interviews represent the DfX activities in the studied companies in a versatile manner. In addition, the flow of product and process requirements was analysed. The results were scrutinised by reflecting them against the existing literature. The results of the analysis are presented in the section 4 Results and analysis. 


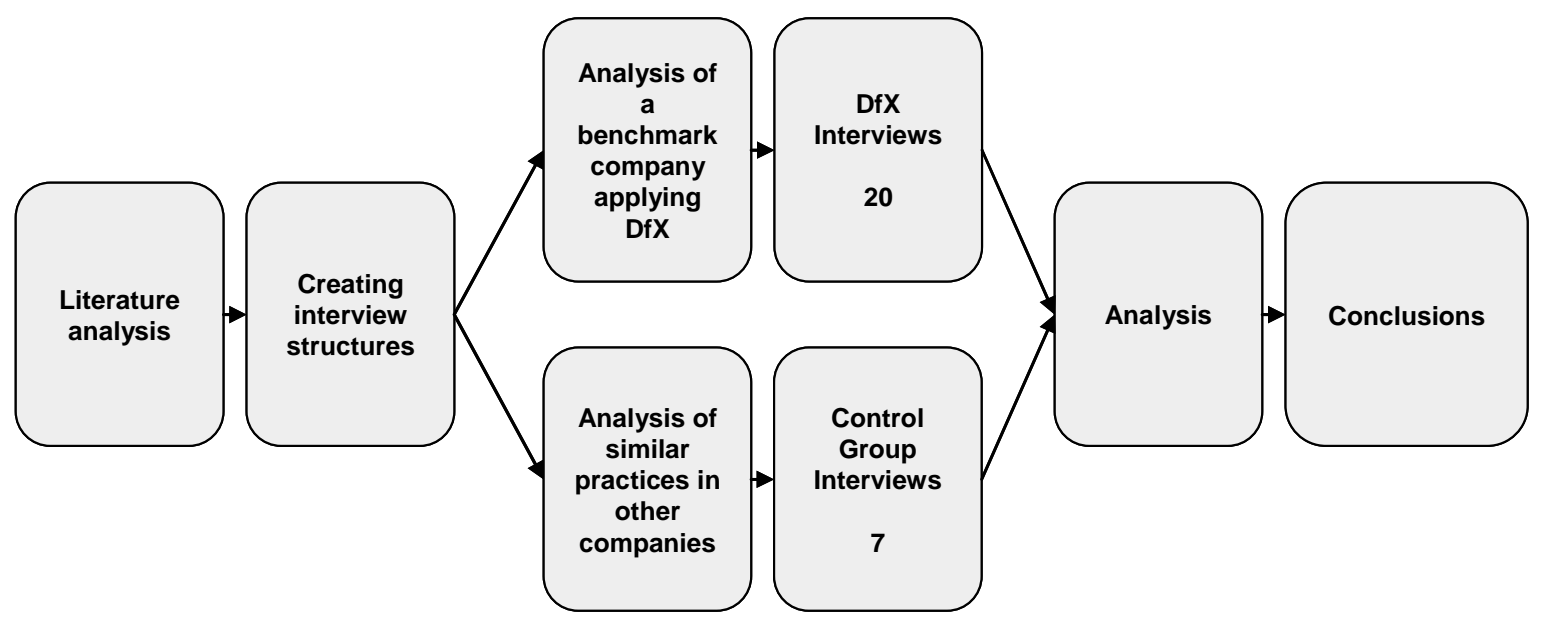

Figure 1. The research process.

\section{Results and Analysis}

\subsection{DfX in the Large Benchmark Company}

The benchmark company interviewees regard it essential for business to guarantee an adequate delivery capability. Only functional products that are delivered according to contractual terms have value from customers' perspective. The benchmark company makes continuous efforts to rationalise its internal processes to achieve the optimum with regards to desired competitive goals. As an example, capability to deliver can to some degree be considered as a detached goal within production, but it may not be adequate to obtain sufficient results. As a result, the studied benchmark company exploits the DfX concept to tackle these challenges already during the early stages of product development.

The role of DfX is seen to be ensuring that the needs of manufacturing, supply chain, and after-sales service are catered for during PD. Each DfX discipline is divided into smaller operational entities, sub-disciplines. For example, manufacturing aspects have been divided into board assembly, final assembly, testing, and packaging. Supply chain aspects cover both, the structure and the players of the supply chain, and the more operational aspects of striving to realise any desired competitive goals. Important aspects are seen to include cost, delivery, service, environment, and quality. The company has a specific DfX management organisation in place to coordinate different DfX disciplines and to communicate their needs into product development and order delivery processes. The subject for communication is requirements set by different disciplines. A named responsible manager has been appointed for each DfX discipline. Figure 2 illustrates the DfX system of the benchmark company.

DfX activities in the studied large benchmark com- pany are divided into five separate disciplines, including design for supply chain, design for environment, design for quality, design for manufacturing, and design for service. Each discipline has its own responsible manager assuring adequate implementation and training. DfX disciplines are further divided into a number of sub-disciplines. Different DfX disciplines are coordinated by a director, appointed to harmonise and develop the entire DfX organisation. DfX organisation has a role in collecting and disseminating best practices and requirement into product development and order delivery processes. These requirements include both internal and external aspects to the company.

Requirements set by individual DfX disciplines are communicated into product development through a specific DfX management organisation. Training sessions are organised for product development personnel to support this communication. Also, each DfX discipline has named specialists in PD projects, facilitating on-line feedback. Requirements of each DfX discipline can be categorised by using the following hierarchy: 1) Legislation and business sector standards, 2) Company strategy and business targets, 3) Customers, 4) Internal customers, and 5) Supply chain.

The benchmark company often receives customer requests with special requirements. In this type of cases the company needs to know whether standard products are adequate, or whether product development efforts are required. DfX requirements are then one of the inputs for a product line specific decision-making gate, used for stakeholder and requirements analysis.

\subsection{Analysis of DfX in the Benchmark Company}

Design for $\mathrm{X}$ has been conducted for a long period of time, in the benchmark company, and is seen to function 


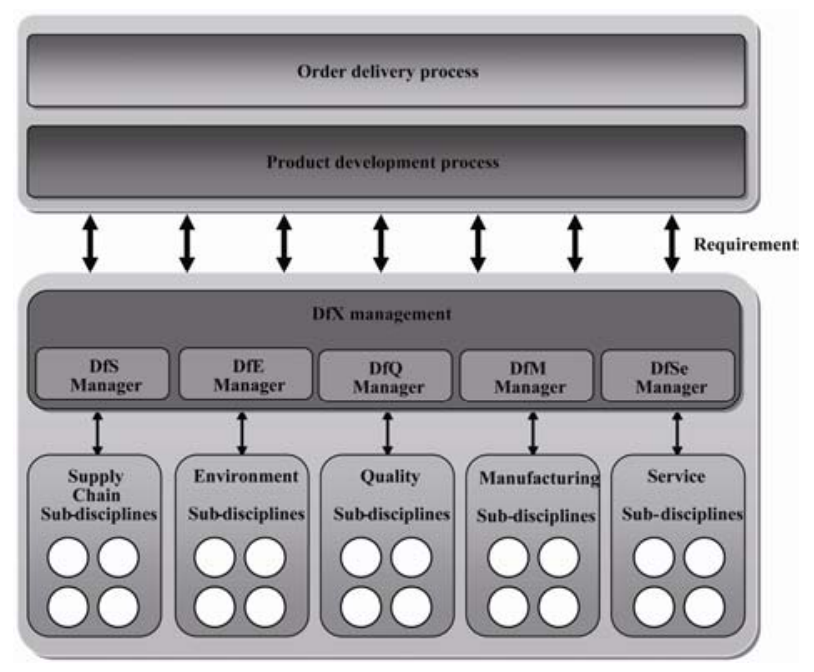

Figure 2.The DfX system of the benchmark company.

well. At a higher level DfX activities are seen to provide principles and general guidelines for product development. At practical level, DfX means exact, often numerical, requirements, tools, and design rules. The utilisation of DfX concept has developed and now covers a wide set of activities, including supply chain aspects, reliability, environment and such. However, DfX is seen to have challenges and is improved continuously.

The organisation of the studied benchmark company is large and complex, resulting in challenges in communication. A single employee can have several roles amplifying the challenge. Employees have a tendency to understand requirements in different ways in diverse product development functions and divisions. System, mechanical, electronics, and software designers all have their own views and perspectives. In addition, different business units and cultural diversity in the global organisation add on to the communication challenge. There are also different ways of workings in different DfX disciplines due to historical reasons, potentially causing some conflicts.

Requirements are seen important to be prioritised from the business perspective; however, there is no adequate commensurability. In practice, this means that it is difficult to compare different and sometimes conflicting requirements, as they do not have common economic scale for comparison. The requirements are attempted to prioritise based on end-to-end cost calculations, however, employees are often sceptical about calculations made by other people. As an example, customer requirements on increasing the number of product titles, is in conflict with the desire to minimise the number of product titles. Currently, requirements are too often prioritised based on individuals' capability to sell their viewpoint. Product development projects do not always rank the require- ments set by individual DfX disciplines as primary issues; especially should the volumes be low. The fact is that people are different and the processes are not always standardised.

It seems that DOORS ${ }^{\circledR}$ has been chosen as the common data system to communicate requirements between DfX disciplines and product development. However, it is not applied company wide, also other tools exist, and the functioning of DOORS ${ }^{\circledR}$ is seen non-optimal. It is seen to take a lot of experience to formulate requirements into numerical terms, in order to product development personnel to understand. Also, for database purposes the requirements are seen vital to be numerical.

In some cases, the research and development organisation has technology development project before product development projects, they design ASICs (application specific integrated circuit), product architecture, and choose technologies. Often these choices are close to the final solutions, causing difficulties, should for example the manufacturing aspect not be addressed early enough.

According to the interviewees, due to the global changes in their conglomerate, some functions, such as testing have had to go back-to-basics, in their approach to emphasise manufacturing and desired competitive goals, on the expense of the entire product life-cycle. Product lines have been vast in the global organisation, causing additional challenges for managing requirements.

Currently bonuses in product development depend on keeping up to schedules, not on how they serve the internal customers in the following phases. This makes it difficult for DfX disciplines to sell any life-cycle aspects.

Table 2 summarises the key findings of DfX in the benchmark company.

\subsection{DfX Practices in the Control Group Companies}

Practices also typical to DfX methodologies, and organising related functions and requirements, are conducted

Table 2. Key findings.

\begin{tabular}{|c|c|}
\hline Activity & Role \\
\hline DfX management & Coordination \\
\hline \multirow{2}{*}{ Cost calculations } & Prioritisation \\
\hline & Communication \\
\hline $\begin{array}{l}\text { Requirements } \\
\text { screening }\end{array}$ & Prioritisation \\
\hline $\begin{array}{l}\text { Organisational } \\
\text { location }\end{array}$ & Role to minimise costs \\
\hline Focal Point $^{\mathrm{TM}}$ & Tools/data systems: management \& engi- \\
\hline DOORS $^{\circledR}$ & neering \\
\hline
\end{tabular}


in a slightly different manner in the control group companies. All the companies do not necessarily recognise the term DfX, or knowingly utilise these methodologies. The studied control group companies, mostly small and medium sized enterprises (SME) do include few companies that can be categorised as large, but are smaller in size than the large benchmark company.

The interviewed SMEs are seen to utilise ordinary project management solutions for handling internal requirements. These solutions include utilisation of project managers and project meetings for coordination of aspects also typical to DfX. In addition, some SMEs have separate meetings for different design areas to ensure proper coordination. The responsibility of production manager is seen to include assuring the inclusion of manufacturing requirements, either through personal attendance, or appointing someone from the production organisation.

The interviewed large companies use similar project management solutions as the SMEs. In addition, some of them utilise new product introduction (NPI) groups to assure fluent production ramp-ups, and separate supply chain management (SCM) groups for outsourced production.Company quality organisation is also seen to have an influence over managing aspects that are also typical for DfX practices.

\subsection{Comparison of DfX Practises in the Studied Companies}

There are some differences among the studied large benchmark company, in relation to organising DfX practices, and the way similar practices are dealt with in the control group companies. Some of the smaller companies do not knowingly utilise the term DfX, but the goal and the content of their activities is similar.

The main difference between the benchmark company and the other interviewed companies is the separate DfX organisation and appointed DfX discipline owners. This arrangement enables the benchmark company to manage and communicate requirements through total cost calculations, and written guidelines, documents and data systems, making requirements management more systematic and effective. The experience by the benchmark company highlights that DfX is a concrete way to manage complex and sometimes conflicting requirements. The control group companies tend to utilise more or less ad hoc solutions and are forced to operate more in a firefighting mode. However, noteworthy is that all the smaller companies do not necessarily have acute needs to be as structured in managing their requirements. Also, the control group companies do not necessarily consider the utilised methodologies as a means for achieving com- petitive goals, as for example the large benchmark company does.

Tables 3 and $\mathbf{4}$ summarise the central findings of the empirical results in different companies.

\section{Conclusions}

Companies of the ICT sector work in a multi-project, multi-site, multi-cultural, multi-vendor business environment and organisational changes are frequent. High product complexity and fierce price erosion are typical characteristics in this environment. This forces companies to an ongoing process of streamlining and improving their efficiency, including communication. DfX methodology has proved a functional means for addressing the desire for efficiency and effectiveness improvements and acknowledging the needs of internal customers. DfX is used as a communication tool to achieve functional integration, and is a tangible way to manage requirements throughout product development, starting from the early stages.

DfX can be seen as a management approach for coordinating design requirements of both internal functions and external supply chain partners. Aside the requirements coordination role, DfX can also be utilised to achieve desired competitive goals that are vital for company's success. These goals can include aspects enabling effectiveness in relation to cost, delivery, service, environment, quality, and user experience, among others. The concept is also seen as a mean to cope with the resources

Table 3. Organising DfX activities in the benchmark company, including addressing requirements.

\begin{tabular}{ll}
\hline PD & Benchmark company \\
characteristics & fully modelled \\
wractical & guil documented \\
realisation & cross-functional teams \\
& cost calculations \\
& discipline owners \\
& DfX management organisation \\
Knowledge & requirements formulation \\
iransfer & internal training \\
& design guidelines \\
& DOORS ${ }^{\circledR}$ \& Focal point ${ }^{\mathrm{TM}}$ tools \\
& programme manager \\
& programme meetings \\
& NPI group \\
& company quality organisation \\
DfX management \\
milestone meetings \\
DfX discipline owners \\
\hline
\end{tabular}


Table 4. Organising activities typical to DfX in control group companies, includes addressing requirements.

\begin{tabular}{|c|c|}
\hline & Control group companies \\
\hline $\begin{array}{l}\text { PD } \\
\text { characteristics }\end{array}$ & $\begin{array}{l}\text { roughly or moderately modelled process } \\
\text { checklists, templates, milestone reviews, detailed } \\
\text { project plans, manuals } \\
\text { strict supervision } \\
\text { quality reviews } \\
\text { process ownerships } \\
\text { processes updated 2-4 times a year }\end{array}$ \\
\hline $\begin{array}{l}\text { Practical } \\
\text { realisation }\end{array}$ & $\begin{array}{l}\text { cross-functional project teams } \\
\text { concept owners collect requirements from internal } \\
\text { customers } \\
\text { fire-fighting mode instead of full optimisation } \\
\text { (SME's) } \\
\text { heavy focus on design phase, only minor during } \\
\text { pre-study (SME's) } \\
\text { design guidelines - partially } \\
\text { design manuals - only occasionally } \\
\text { integrated in company quality system } \\
\text { each programmer is responsible for downstream } \\
\text { aspects, e.g. unit tests } \\
\text { programmer/tester pair - agile SW development } \\
\text { checklists, reference manuals, coding guidelines } \\
\text { emphasis on pre-study (Large) } \\
\text { practical optimisation and problem solving to- } \\
\text { gether with manufacturing sub-contractors (SMEs) } \\
\text { daily milestone meetings } \\
\text { attempts to systematically optimise } \\
\text { separate research/piloting/evaluation projects }\end{array}$ \\
\hline $\begin{array}{l}\text { Knowledge } \\
\text { transfer }\end{array}$ & $\begin{array}{l}\text { after-sales feedback prior to project start } \\
\text { lessons learned from previous projects } \\
\text { pilot projects } \\
\text { internal training } \\
\text { feedback from prototypes } \\
\text { communication at all levels } \\
\text { personal communication and meetings instead of } \\
\text { proper documentation (SMEs) } \\
\text { electronic communication } \\
\text { emphasis of knowledge sharing on documents } \\
\text { useful knowledge is transformed into guidelines } \\
\text { DOORS }{ }^{\circledR} \text { tool } \\
\text { knowledge transfer between partners }\end{array}$ \\
\hline Management & $\begin{array}{l}\text { programme meetings } \\
\text { NPI group } \\
\text { company quality organisation } \\
\text { milestone meetings } \\
\text { separate meetings for different design areas (SMEs) } \\
\text { SCM group for outsourced production } \\
\text { programme manager } \\
\text { project manager } \\
\text { production manager }\end{array}$ \\
\hline
\end{tabular}

for release/product realisation. However, one of the main benefits of DfX is getting requirements on equal terms. This virtual equality among requirements enables analysing potential conflicts in stakeholder interests, improving communication, and possibly opening opportunities for forecasting future challenges.

The benchmark company has extensive experience over DfX, for over a decade. The role of DfX is seen to be ensuring that the needs of manufacturing, supply chain, and after-sales service are taken into account during product development. DfX in the studied benchmark company is divided into five separate disciplines, each of which is further divided into smaller operational entities, sub-disciplines. For example, manufacturing aspects have been divided into board assembly, final assembly, testing, and packaging, while supply chain aspects cover both, the structure and the players of the supply chain. New X's are introduced and implemented, and the role of old disciplines may change. DfX concept is organised especially to act as a communication tool, to achieve functional integration, and to act as a tangible way to manage requirements. DfX requirements, in the benchmark company, are one of the inputs for a product line specific gate, utilised for stakeholder analysis.

The control group companies tend to utilise more or less ad hoc solutions and are forced to operate more in a fire-fighting mode. However, noteworthy is that smaller companies do not necessarily have as acute needs to be as structured in managing their requirements. Also, the control group companies do not necessarily consider the utilised methodologies as means for achieving company's competitive goals, the same ways as the benchmark company.

The way DfX is organised in the studied companies proves, in contrast to some literature, that DfX is not a philosophy, but rather works through tangible design guidelines, prototype iterations and tools. Managers of the control group companies could learn from these examples, especially the one of the benchmark company, at three levels: how to manage DfX organisation, practical realisation of DfX, including individual sub-disciplines, and the way DfX is used for coordination, communication and requirements prioritisation. Also, opposed to some authors [6], different DfX disciplines should not be addressed as separate entities, but they must be managed by a DfX manager who has the authority over all the disciplines and whose organisational position is high enough.

In an environment with organisational changes, and acquisitions, companies may be forced to concentrate on critical matters and to go back-to-basics. For example, in order to assure desired competitive goals, a company may be forced to focus only on certain aspects, such as 
manufacturing on the expense of the entire product life-cycle. Life-cycle aspects can only be considered after manufacturing aspects are stabile enough.

This study describes DfX activities in a number of ICT companies that are successful in their fields. Concentrating on a relatively small number of companies enabled a more thorough analysis, and concrete descriptions on how DfX is realised in practice. The interviews covered all the key persons involved in DfX, providing a comprehensive view. The obtained results could vary to some degree, should a wider set of companies and a higher number of interviewees be included in the study. In addition, potential future research could include analysing DfX from the viewpoint of product development projects \& personnel, and especially stakeholder analysis. Companies in this business sector often receive special customer requirements, increasing pressures to tailor products. An interesting topic for further research is DfX's role in addressing such pressures.

\section{Acknowledgements}

This research was conducted as a part of ITEI-ITEA2 efforts.

\section{References}

[1] C. Zeidler, C. Kittl and O. Petrovic, "An Integrated Product Development Process for Mobile Software," International Journal of Mobile Communications, Vol. 6, No. 3, 2007, pp. 345-356.

[2] G. Pahl, W. Beitz, J. Feldhusen, K. H. Grote, K. Wallace and L. Blessing, "Engineering Design - a Systematic Approach,” 3rd Ed., Springer-Verlag, London, 2007.

[3] P. Belt, J. Harkonen, M. Mottonen, P. Kess and H. Haapasalo, "Improving the Efficiency of Verification and Validation,” International Journal of Services and Standards, Vol. 4, No. 2, 2008, pp. 150-166. doi:10.1504/IJSS.2008.016630

[4] P. Helo, "Managing Agility and Productivity in the Electronics Industry,” Industrial Management \& Data Systems, Vol. 104, No. 7, 2004. pp. 567-577. doi:10.1108/02635570410550232

[5] L. Bengtsson and C. Berggren, “The Integrator's New Advantage - the Reassessment of Outsourcing and Production Competence in a Global Telecom Firm," European Management Journal, Vol. 26, No. 5, 2008, pp. 314-324.

[6] J. G. Bralla, "Design for Excellence,” 1st Ed., McGrawHill, New York, 1996.

[7] K. W. Lau, R. C. M. Yam and E. P. Y. Tang, "Supply Chain Product Co-Development, Product Modularity and Product Performance: Empirical Evidence from Hong Kong Manufacturers," Industrial Management \& Data Systems, Vol. 107, No. 7, 2007, pp. 1036-1065.

\section{doi:10.1108/02635570710816739}

[8] J. Harkonen, P. Belt, M. Mottonen, P. Kess and H. Haapasalo, "Maturity of Verification and Validation in ICT Companies," International Journal of Innovation and Learning, Vol. 6, No. 1, 2009, pp. 33-50. doi:10.1504/IJIL.2009.021681

[9] C. C. Yang, S. H. Chen and J. Y. Shiau, "A DfX and Concurrent Engineering Model for the Establishment of a New Department in a University," International Journal of Production Economics, Vol. 107, No. 1, 2007, pp. 179189. doi:10.1016/j.ijpe.2006.08.009

[10] B. Verworn, C. Herstatt and A. Nagahira, "The Fuzzy Front End of Japanese New Product Development Projects: Impact on Success and Differences between Incremental and Radical Projects," R\&D Management, Vol. 38, No. 1, 2008, pp. 1-19. doi:10.1111/j.1467-9310.2007.00492.x

[11] D. A Gatenby and G. Foo, "Design for X (DfX): Key to Competitive, Profitable Products," AT\&T Technical Journal, Vol. 69, No. 3, 1990, pp. 2-13.

[12] J. Jiang, M. Shiu and M. Tu, "DfX and DfSS: How QfD Integrates Them,” Quality Progress, Vol. 40, No. 10, 2007, pp. 45-52.

[13] E. Gubi and J. Heikkila, "Concurrent Product and Demand Chain Creation - in Search of Contingencies and Strategic Choices," EurOMA/POMS Conference, Como, Italy, 2003.

[14] R. Maltzman, K. M. Rembis, M. Donisi, M. Farley, R. C. Sanchez and A. Y. Ho, "Design for Networks - the Ultimate Design for X,” Bell Labs Technical Journal, Vol. 9, No. 4, 2005, pp. 5-23. doi:10.1002/bltj.20057

[15] R. G. Cooper, S. J. Edgett and E. J. Kleinschmidt, "Benchmarking Best NPD Practices - III," Research Technology Management, Vol. 47, No. 6, 2004, pp. 43-55.

[16] Gupta, K. S. Pawara and P. Smart, "New Product Development in the Pharmaceutical and Telecommunication Industries: A Comparative Study,” International Journal of Production Economics, Vol. 106, No. 1, 2007, pp. 41-60. doi:10.1016/j.ijpe.2006.04.008

[17] T. C. Kuo, S. H. Huang and H. C. Zhang, "Design for Manufacture and Design for ' $\mathrm{X}$ ': Concepts, Applications, and Perspectives," Computers \& Industrial Engineering, Vol. 41, No. 3, 2001, pp. 241-260. doi:10.1016/S0360-8352(01)00045-6

[18] M. Bruce, R. Cooper, B. Morris and A. Wootten, "Managing Requirements Capture within a Global Telecommunications Company," R\&D Management, Vol. 29, No. 2, 1999, pp. 107-120. doi:10.1111/1467-9310.00122

[19] K. W. Jablokow and D. E. Booth, “The Impact and Management of Cognitive Gap in High Performance Product Development Organizations," Journal of Engineering and Technology Management, Vol. 23, No. 4, 2006, pp. 313-336. doi:10.1016/j.jengtecman.2006.08.003

[20] M. Mottonen, J. Harkonen, P. Belt, H. Haapasalo and J. Simila, "Managerial View on Design for Manufacturing," Industrial Management \& Data Systems, Vol. 109, No. 6, 
2009, pp. 859-872. doi:10.1108/02635570910968081

[21] S. Spahi and Y. Hosni, "Optimising the Degree of Customisation for Products in Mass Customisation Systems," International Journal of Mass Customisation, Vol. 3, No. 1, 2009, pp. 82-114. doi:10.1504/IJMASSC.2009.021662

[22] G. Boothroyd, W. Knight and P. Dewhurst, "Product Design for Manufacture and Assembly,” 2nd Ed., Marcel Dekker, New York, 2001.

[23] G. Boothroyd, P. Dewhurst and W. Knight, "Product Design for Manufacture and Assembly,” Illustration Edition, Marcel Dekker, New York, 1994.

[24] G. Q. Huang, "Implementing Design for X Tools, In: G. Q. Huang, Ed. Design for X: Concurrent Engineering Imperatives,” 1st Ed., Chapman \& Hall, London, 1996.

[25] S. H. Huang, T. C. Kuo and H. C. Zhang, "Design for Manufacture and Design for ' $\mathrm{X}$ ': Concepts, Applications, and Perspectives," Computers \& Industrial Engineering, Vol. 41, No. 3, 2001, pp. 241-260. doi:10.1016/S0360-8352(01)00045-6

[26] C. H. Fine, "Clockspeed: Winning Industry Control in the Age of Temporary Advantage,” Perseus Books, New York, 1998.

[27] R. K. Srivastava, T. A. Shervani and L. Fahey, "Marketing, Business Processes, and Shareholder Value: An Organizationally Embedded View of Marketing Activities and the Discipline of Marketing," The Journal of Marketing, Vol. 63, 1999, pp. 168-179. doi:10.2307/1252110

[28] Griffin, "Modeling and Measuring Product Development Cycle Time Across Industries,” Journal of Engineering and Technology Management, Vol. 14, No. 1, 1997, pp. 1-24. doi:10.1016/S0923-4748(97)00004-0

[29] L. M. Birou and S. E. Fawcett, "Supplier Involvement in Integrated Product Development," International Journal of Physical Distribution \& Logistics Management, Vol. 24, No. 5, 1994, pp. 4-14. doi:10.1108/09600039410063982

[30] R. Van Dierdonck, "The Manufacturing/Design Interface," $R \& D$ Management, Vol. 20, No. 3, 1990, pp. 203-209. doi:10.1111/j.1467-9310.1990.tb00710.x

[31] J. M. Morgan and J. K. Liker, "The Toyota Product Development System: Integrating People, Process, and Technology,” Productivity Press, New York, 2006.

[32] P. Hines, M. Francis and P. Found, “Towards Lean Product Lifecycle Management: A Framework for New Product Development," Journal of Manufacturing Technology Management, Vol. 17, No. 7, 2006, pp. 866-887. doi:10.1108/17410380610688214

[33] D. N. Ford and D. K. Sobek II, “Adapting Real Options to New Product Development by Modeling the Second Toyota Paradox," IEEE Transactions on Engineering Management, Vol. 52, No. 2, 2005, pp. 175-185. doi:10.1109/TEM.2005.844466

[34] H. S. Abdalla, "Concurrent Engineering for Global Manufacturing," International Journal of Production Economics, Vol. 60-61, 1999, pp. 251-260. doi:10.1016/S0925-5273(98)00152-2

[35] N. King and A. Majchrzak, "Concurrent Engineering Tools: Are the Human Issues Being Ignored?,” IEEE
Transactions on Engineering Management, Vol. 43, No. 2, 1996, pp. 189-201. doi:10.1109/17.509984

[36] S. K. Fixson, "Product Architecture Assessment: A Tool to Link Product, Process, and Supply Chain Design Decisions,” Journal of Operations Management, Vol. 23, No. 3-4, 2005, pp. 345-369. doi:10.1016/j.jom.2004.08.006

[37] Grossler and A. Grubner, "An Empirical Model of the Relationships between Manufacturing Capabilities,” International Journal of Operations \& Production Management, Vol. 26, No. 5, 2006, pp. 458-485.

[38] X. Koufteros, M. Vonderembse and W. Doll, "Concurrent Engineering and Its Consequences," Journal of Operations Management, Vol. 19, No. 1, 2001, pp. 97-115. doi:10.1016/S0272-6963(00)00048-6

[39] Y. Asiedu, "Product Life Cycle Cost Analysis: State of the Art Review," International Journal of Production Research, Vol. 36, No. 4, 1998, pp. 883-908. doi:10.1080/002075498193444

[40] D. M. Anderson, "Design for Manufacturability \& Concurrent Engineering,” CIM Press, California, Cambria, 2006.

[41] S. Rabino and A. Wright, “Accelerated Product Introductions and Emerging Managerial Accounting Perspectives: Implications for Marketing Managers in the Technology Sector,” Journal of Product Innovation Management, Vol. 10, No. 2, 2003, pp. 126-135. doi:10.1016/0737-6782(93)90004-A

[42] M. L. Li, "Product Structure Management (PSM) \& Profitability,” PSM \& Profitability, 2008, pp. 1-7.

[43] L. M. Birou, S. E. Fawcett and G. M. Magnan, "The Product Life Cycle: A Tool for Functional Strategic Alignment," International Journal of Purchasing and Materials Management, Vol. 34, No. 2, 2006, pp. 37-52.

[44] M. Swink and M. H. Way, "Manufacturing Strategy: Propositions, Current Research, Renewed Directions," International Journal of Operations \& Production Management, Vol. 15, No. 7, 1995, pp. 4-26. doi:10.1108/01443579510090381

[45] G. M. Magnan, S. E. Fawcett and L. M. Birou, "Benchmarking Manufacturing Practice Using the Product Life Cycle,” Benchmarking: An International Journal, Vol. 6, No. 3, 1999, pp. 239-253.

[46] J. S. Kim and P. Arnold, "Manufacturing Competence and Business Performance: A Framework and Empirical Analysis," International Journal of Operations \& Production Management, Vol. 13, No. 10, 1993, pp. 4-25. doi:10.1108/01443579310045518

[47] G. Pahl, W. Beitz, K. Wallace, L. Blessing and F. Bauert, "Engineering Design: A Systematic Approach," 2nd Ed., Springer, England, 1996.

[48] Gunasekaran, “Agile Manufacturing: Enablers and an Implementation Framework," International Journal of Production Research, Vol. 36, No. 5, 1998, pp. 12231247. doi:10.1080/002075498193291

[49] Y. M. Chen and J. J. Liu "Cost-Effective Design for Injection Molding," Robotics and Computer-Integrated Manufacturing, Vol. 15, No. 1, 1999, pp. 1-21. 


\section{doi:10.1016/S0736-5845(99)00005-8}

[50] E. M. Shehab and H. S. Abdalla, "Manufacturing Cost Modelling for Concurrent Product Development," Robotics and Computer-Integrated Manufacturing, Vol. 17, No. 4, 2001, pp. 341-353. doi:10.1016/S0736-5845(01)00009-6

[51] C. Ou-Yang and T. S. Lin, "Developing an Integrated Framework for Feature-Based Early Manufacturing Cost Estimation,” The International Journal of Advanced Manufacturing Technology, Vol. 13, No. 9, 2005, pp. 618-629. doi:10.1007/BF01350820

[52] J. D. Booker, "Industrial Practice in Designing for Quality,” International Journal of Quality \& Reliability Management, Vol. 20, No. 3, 2003, pp. 288-303. doi:10.1108/02656710310461305

[53] B. J. C. Babu, R. T. D. Prabhakaran and V. P. Agrawal, "DfX Analysis Applied to Composite Products," Journal of Reinforced Plastics and Composites, Vol. 27, No. 3, 2008, pp. 287-312. doi:10.1177/0731684407083010

[54] Subramani and P. Dewhurst, "Efficient Design for Service Considerations," Manufacturing Review, Vol. 6, No. 1, 1993, pp. 40-47.

[55] J. Gershenson and K. Ishii, "Life-Cycle Serviceability Design,” In A. Kusiak, Ed. Concurrent Engineering: Automation, tools and techniques, Wiley-Interscience, New York, 1993, pp. 363-384.

[56] J. K. Gershenson and G. J. Prasad, "Product Modularity and Its Effect on Service and Maintenance," Proceedings of the Maintenance and Reliability Conference, Knoxville, Tennessee, May 1997.

[57] K. Goffin and C. New, "Customer Support and New Product Development - an Exploratory Study," International Journal of Operations \& Production Management, Vol. 21, No. 3, 2001, pp. 275-301. doi:10.1108/01443570110364605

[58] S. Cavalieri, P. Gaiardelli and S. Ierace, “Aligning Strategic Profiles with Operational Metrics in After-Sales Service," International Journal of Productivity and Performance Management, Vol. 56, No. 5/6, 2007, pp. 436455. doi:10.1108/17410400710757132

[59] M. Antioco, R. K. Moenaert, R. A. Feinberg and M. G. M. Wetzels, "Integrating Service and Design: The Influences of Organizational and Communication Factors on Relative Product and Service Characteristics," Journal of the Academy of Marketing Science, Vol. 36, No. 4, 2008, pp. 501-521. doi:10.1007/s11747-008-0097-X

[60] Gupta, W. A. Wallace and N. K. Sondheimer, "Functional Guarantees: A New Service Paradigm,” International Journal of Product Development, Vol. 5, No. 1-2, 2008, pp. 153-175. doi:10.1504/IJPD.2008.016375

[61] T. Naslund and J. Lowgren, "Usability Inspection in Contract-Based Systems Development - a Contextual Assessment," Journal of Systems and Software, Vol. 45, No. 3, 1999, pp. 233-240. doi:10.1016/S0164-1212(98)10082-1

[62] T. Kaski and J. Heikkila, "Measuring Product Structures to Improve Demand-Supply Chain Efficiency," Interna- tional Journal of Technology Management, Vol. 23, No. 6, 2002, pp. 578-598. doi:10.1504/IJTM.2002.003027

[63] K. W. Lau, R. C. M. Yam and E. Tang, “The Impacts of Product Modularity on Competitive Capabilities and Performance: An Empirical Study,” International Journal of Production Economics, Vol. 105, No. 1, 2007, pp. 1-20. doi:10.1016/j.ijpe.2006.02.002

[64] M. L. Swink and R. Calantone, "Design-Manufacturing Integration as a Mediator of Antecedents to New Product Design Quality," IEEE Transactions on Engineering Management, Vol. 51, No. 4, 2004, pp.472-482. doi:10.1109/TEM.2004.835088

[65] R. W. Schmenner and M. V. Tatikonda, "Manufacturing Process Flexibility Revisited," International Journal of Operations \& Production Management, Vol. 25, No. 12, 2005, pp. 1183-1189. doi:10.1108/01443570510633585

[66] S. Vehtari, “The Dynamics Involved with Manufacturing Capabilities towards a Competitive Advantage," series 2006/1, Helsinki University of Technology, Helsinki, 2006.

[67] Y. Liu, Y. Li and Z. Wei, "How Organizational Flexibility Affects New Product Development in an Uncertain Environment: Evidence from China," International Journal of Production Economics, Vol. 120, No. 1, 2009, pp. 18-29. doi:10.1016/j.ijpe.2008.07.026

[68] J. Bralla, “Design for Manufacturability Handbook,” 2nd Ed., McGraw-Hill Professional, New York, 1998.

[69] S. H. Huang, G. Wang and J. P. Dismukes, “A Manufacturing Engineering Perspective on Supply Chain Integration," Proceedings of the 10th International Conference on Flexible Automation and Intelligent Manufacturing, Maryland, USA, 2000, pp. 204-214.

[70] N. R. Joglekar and S. R. Rosenthal, "Coordination of Design Supply Chains for Bundling Physical and Software Products," Journal of Product Innovation Management, Vol. 20, No. 5, 2003, pp. 374-390. doi:10.1111/1540-5885.00035

[71] J. Lamothe, K. Hadj-Hamou and M. Aldanondo, “An Optimization Model for Selecting a Product Family and Designing Its Supply Chain,” European Journal of Operational Research, Vol. 169, No. 3, 2006, pp. 10301047. doi:10.1016/j.ejor.2005.02.007

[72] T. W. Williams and K. P. Parker, "Design for Testability: a Survey,” Proceedings of the IEEE, Vol. 71, No. 1, 1983, pp. 98-112. doi:10.1109/PROC.1983.12531

[73] J. P. Teixeira, I. C. Teixeira, C. F. B. Almeida, F. M. Gonçalves and J. Gonçalves, "A Methodology for Testability Enhancement at Layout Level,” Journal of Electronic Testing, Vol. 1, No. 4, 1990, pp. 287-299. doi:10.1007/BF00136317

[74] R. V. Binder, "Design for Testability in Object-Oriented Systems," Communications of the ACM, Vol. 37, No. 9, 1994, pp. 87-101. doi:10.1145/182987.184077

[75] P. S. Parikh and M. Abramovici, “Testability-Based Partial Scan Analysis,” Journal of Electronic Testing, Vol. 7, No. 1-2, 1995, pp. 61-70. doi:10.1007/BF00993314 
[76] D. Wang, Y. Hu, H. W. Li and X. W. Li, "Design-ForTestability Features and Test Implementation of a Giga Hertz General Purpose Microprocessor," Journal of Computer Science and Technology, Vol. 23, No. 6, 2008, pp. 1037-1046. doi:10.1007/s11390-008-9193-0

[77] J. M. Solana, "Reducing Test Application Time, Test Data Volume and Test Power through Virtual Chain Partition," Integration the VLSI Journal, Vol. 42, No. 3, 2009, pp. 385-399. doi:10.1016/j.vlsi.2008.12.001

[78] T. Dowie, "Green Design," World Class Design to Manufacture, Vol. 1, No. 4, 1994, pp. 32-38. doi:10.1108/09642369210063045

[79] J. R. Fiksel, "Design for Environment: Creating EcoEfficient Products and Processes," McGraw-Hill, New York, 1996.

[80] Gungor and S. M. Gupta, "Issues in Environmentally Conscious Manufacturing and Product Recovery: A Survey," Computers \& Industrial Engineering, Vol. 36, No. 4, 1999, pp. 811-853. doi:10.1016/S0360-8352(99)00167-9

[81] F. Kurk and P. Eagan, "The Value of Sdding Design-For-The-Environment to Pollution Prevention Assistance Options," Journal of Cleaner Production, Vol. 16, No. 6, 2008, pp. 722-726. doi:10.1016/j.jclepro.2007.02.022

[82] W. Eversheim and M. Baumann, “Assembly-Oriented
Design Process,” Computers in Industry, Vol. 17, No. 2-3, 1991, pp. 287-300. doi:10.1016/0166-3615(91)90041-7

[83] C. Poli and W. A. Knight, "Design for Forging HandBook,” Technical Report, Mechanical Engineering Department, University of Massachusetts, Dartmouth, MA, 1984.

[84] G. Q. Huang and K. L. Mak, "Internet Applications in Product Design and Manufacturing,” 1st Ed., Springer, Berlin, 2003.

[85] H. Meerhamm, "Design for X - a Core Area of Design Methodology," Journal of Engineering Design, Vol. 5, No. 2, 1994, pp. 145-163.

[86] S. Y. T. Lang, J. Dickinson and R. O. Buchal, "Cognitive Factors in Distributed Design," Computers in Industry, Vol. 48, No. 1, 2002, pp. 89-98. doi:10.1016/S0166-3615(02)00012-X

[87] J. W. Herrmann, J. Cooper, S. K. Gupta, C. C. Hayes, K. Ishii, D. Kazmer, P. A. Sandborn and W. H. Wood, "New Directions in Design for Manufacturing," Proceedings of the ASME Design Engineering Technical Conferences and Computers and Information in Engineering Conference, Salt Lake City, Utah, 28 September - 2 October, 2004.

[88] R. Merton, M. Fiske and P. Kendall, "The Focused Interview: A Manual of Problems and Procedures,” 2nd Ed., the Free Press, New York, 1990. 